\title{
Perbandingan Keberhasilan dan Kemudahan Intubasi dengan Bonfils antara Teknik Pendekatan Midline dan Retromolar pada Maneken
}

\author{
Anas Alatas ${ }^{1 *}$, Adhrie Sugiarto ${ }^{1}$, Shendy Meike Sari ${ }^{1}$ \\ 1. Departemen Anestesiologi dan Terapi Intensif, Fakultas Kedokteran Universitas Indonesia, \\ RSUPN Dr. Cipto Mangunkusumo, Jakarta, Indonesia
}

\begin{abstract}
ABSTRAK
Latar belakang: Bonfils adalah alat fiberoptik kaku yang dapat digunakan untuk intubasi baik pada jalan napas normal maupun sulit. Penelitian ini membandingkan teknik pendekatan midline dan retromolar dalam melakukan intubasi dengan Bonfils pada suatu pelatihan dengan subjek penelitian adalah PPDS Departemen Anestesiologi dan Terapi Intensif FKUI/RSCM tahap mandiri dan paripurna. Pelatihan pada maneken ini dilakukan di SIMUBEAR (Simulation Based Education and Research Center) IMERI (Indonesian Medical Education and Research Institute). Subjek tidak terbiasa menggunakan Bonfils, sehingga pelatihan ini menjadi kesempatan yang baik. Terdapat 10 langkah DOPS (Direct Observation of Procedural Skills) yang harus dikerjakan oleh setiap subjek untuk masing-masing teknik. Penelitian ini menilai DOPS, lama waktu intubasi, dan jumlah upaya yang dilakukan untuk melakukan intubasi dengan Bonfils.

Metode: Penelitian ini merupakan uji eksperimental, acak, tidak tersamar, crossover yang dilakukan pada bulan September 2018. Subjek penelitian sebanyak 45 orang yang diambil dengan metode total sampling, dibagi menjadi dua kelompok yang berbeda dalam sekuens. Kelompok 1 terdiri dari 23 orang yang melakukan intubasi dengan Bonfils pendekatan midline terlebih dahulu kemudian pendekatan retromolar dan kelompok 2 terdiri dari 22 orang yang melakukan sebaliknya. Uji statistik data kategorik berpasangan menggunakan uji McNemar dan data numerik berpasangan dengan uji Wilcoxon Signed Ranks.

Hasil: Keberhasilan intubasi dengan Bonfils melalui pendekatan midline pada DOPS 1, DOPS 2 dan pada kasus jalan napas sulit sebesar $71,1 \%, 86,7 \%, 88,9 \%$, sedangkan pada pendekatan retromolar adalah $68,8 \%, 68,9 \%, 64,4 \%$. Lama waktu intubasi yang diperlukan untuk pendekatan midline pada jalan napas normal dan sulit adalah 59 (18-224) detik dan 55 (24-146) detik, sedangkan pada pendekatan retromolar adalah 64 (38-200) detik dan 74,5 (26-254) detik. Kemudahan melakukan intubasi dengan Bonfils dinilai dari jumlah upaya yang dilakukan oleh subjek sebanyak $1 x$, yaitu pada pendekatan midline $64,4 \%$ dan retromolar $35,6 \%$ pada jalan napas normal, dan $66,7 \%$ serta $46,7 \%$ pada jalan napas sulit.
\end{abstract}

Simpulan: Keberhasilan dan kemudahan intubasi dengan Bonfils melalui pendekatan midline lebih baik dibandingkan dengan pendekatan retromolar pada maneken.

Kata Kunci: manajemen jalan napas, sulit jalan napas, intubasi, Bonfils, pelatihan 


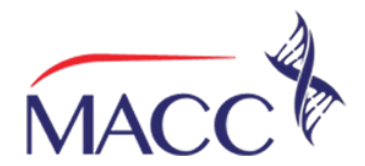

\title{
Comparison of Success and Ease of Intubation with Bonfils between Midline and Retromolar Approach Techniques in Mannequin
}

\author{
Anas Alatas ${ }^{1 *}$, Adhrie Sugiarto ${ }^{1}$, Shendy Meike Sari ${ }^{1}$
}

1. Departement of Anesthesiology and Intensif Care, Faculty of Medicine, Universitas Indonesia, Dr. Cipto Mangunkusumo National General Hospital, Jakarta, Indonesia

*corresponding author

\begin{abstract}
Background: The Bonfils Intubation Fibrescope is a rigid optical instrument for performing orotracheal intubation has becomes a useful device in the management of normal and difficult airways. In this study, we compared midline and retromolar approach techniques using Bonfils in simulation-based training that would allow the highest level residents of Anesthesiology Department perform tracheal intubation faster and a higher success probability. Data were collected from 45 participants using an airway simulator in SIMUBEAR (Simulation Based Education and Research Center) IMERI (Indonesian Medical Education and Research Institute). The participants who uncommon using Bonfils were randomly assigned to a sequence of techniques to use. These two techniques become a challenge for the participants. The ten steps of DOPS (Direct Observation of Procedural Skills) were performed with each technique. We did the assessment of DOPS, time of intubation, and the amount of attempt of intubation.
\end{abstract}

Methods: We did the randomized crossover trials in which participants were assigned randomly to a sequence of techniques using Bonfils with midline and retromolar approach on September 2018. These 45 participants were collected by total sampling method, divided into two groups. Group 1 $(n=23)$ did the intubation using midline approach first then retromolar and group $2(n=22)$ did the retromolar first then midline approach. Each participant was being trained using those techniques by ten steps of DOPS, then they were tested to intubate a mannequin on normal and difficult airways. The researchers obtained the DOPS scores, time of intubation, and the amount of intubation attempts. We analyzed this study using McNemar test for categoric data and Wilcoxon Signed Ranks test for numeric data.

Results: This study compared the success rate, intubaton time and the amount of intubation attempts using Bonfils with midline and retromolar approach. It was found that the success rate in midline approach was better than retromolar. For the ease rate, we obtained data from the intubation time and the amount of intubation attempts. The intubation time in midline approach (59 (18-224) s and 55 (24-146) s) was shorter than retromolar (64 (38-200) s and 74,5 (26-254) s) in normal and difficult airways respectively. And also, we found that $64,4 \%$ participants could do one attempt of intubation using Bonfils with midline approach and only 35,6\% participants did the retromolar approach.

Conclusion: Success and ease rate of intubation using Bonfils with midline approach is better than retromolar approach techniques in mannequin.

Keywords: cairway management, difficult airway, intubation, Bonfils, simulation-based training 


\section{PENDAHULUAN}

Diketahui terdapat sekitar 30\% kejadian mortalitas pada anestesi yang berhubungan dengan manajemen jalan napas. ${ }^{1}$ Bonfils adalah sebuah alat fiberscope dengan struktur kaku yang diciptakan untuk memfasilitasi intubasi orotrakea yang dapat digunakan untuk manajemen jalan napas lanjut jika tidak dapat dilakukan intubasi dengan laringoskop langsung. Pasien dengan keterbatasan dalam pembukaan rongga mulut dan pergerakan pada daerah leher lebih diuntungkan ketika menggunakan Bonfils. $^{2,3}$

Penggunaan Bonfils untuk intubasi dapat melalui dua teknik pendekatan, yaitu pendekatan retromolar dan pendekatan melalui pertengahan bibir (midline). Melalui pendekatan retromolar, scope pada Bonfils dimasukkan dari sisi kanan mulut pasien, menelusuri molar dan dilanjutkan sampai dengan epiglotis. Kemudian scope diteruskan sampai cincin trakea teridentifikasi dan pipa endotrakea dapat dimasukkan ke dalam trakea tersebut. Beberapa penulis mengatakan bahwa teknik pendekatan retromolar ini dapat meningkatkan risiko terjadinya kerusakan trakea, dapat juga terjadi intubasi esofagus atau kerusakan aritenoid jika posisi tip Bonfils berada di luar trakea. ${ }^{2}$

Sebagai alternatif, intubasi dengan menggunakan Bonfils ini dapat dilakukan dengan pendekatan midline untuk dapat mencapai epiglotis. Pendekatan midline ini akan lebih mudah dilakukan bagi pemula pengguna Bonfils. Teknik ini dapat dibantu dengan beberapa teknik manipulasi jalan napas, seperti chin lift, jaw thrust, namun dapat juga menggunakan laringoskop untuk mengidentifikasi rongga retrofaringeal dan ketika tip pipa endotrakea sudah melewati pita suara, laringoskop dapat dikeluarkan dan pipa endotrakea dapat dimasukkan ke dalam trakea. ${ }^{2}$

Terdapat penelitian yang membandingkan pendekatan retromolar/lateral oleh P. Charters (PC) dan pendekatan midline oleh $\mathrm{M}$. Halligan (MH). Lama waktu yang digunakan oleh $\mathrm{MH}$ dan PC untuk melakukan intubasi adalah 44 detik dan 25 detik. ${ }^{4}$ Kedua cara pendekatan penggunaan Bonfils ini, baik pendekatan midline dan retromolar akan berhasil dilakukan jika sering diadakan simulasi untuk meningkatkan keterampilan dan pengetahuan dalam penggunaan alat ini.

Simulasi dengan kualitas baik dapat meningkatkan keberhasilan dan efisiensi pengajaran. DOPS (Direct Observation of Procedural Skills) yang dikembangkan oleh Royal College of Physicians di Inggris, sebagai salah satu metode untuk menilai keterampilan praktik, dinilai praktis, handal, dapat dipercaya, dan mampu laksana. Umpan balik yang diberikan sangat penting sebagai instrumen evaluasi hasil pembelajaran. ${ }^{5}$

Tujuan dari penelitian ini adalah untuk mengetahui keberhasilan dan kemudahan intubasi dengan Bonfils antara teknik pendekatan midline dan retromolar dalam melakukan intubasi pada maneken.

\section{METODOLOGI PENELITIAN}

Rancangan penelitian ini adalah penelitian eksperimental, acak, tidak tersamar, crossover. Kriteria inklusi penelitian ini adalah PPDS Departemen Anestesiologi dan Terapi Intensif FKUI/RSCM tahap mandiri dan paripurna yang bersedia menandatangani lembar persetujuan penelitian. Kriteria eksklusi adalah peserta

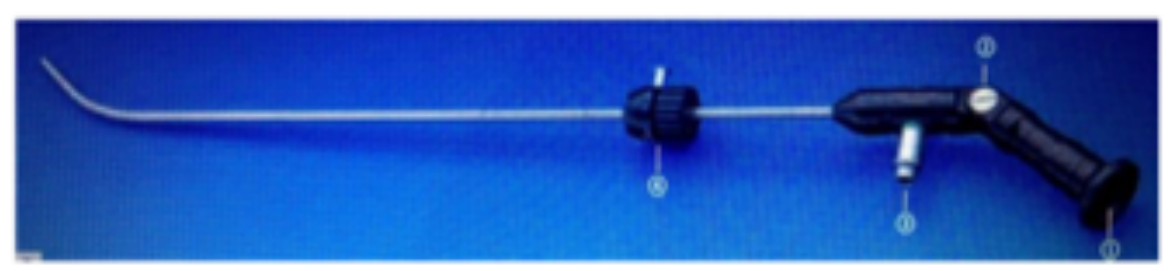

Gambar 1. Bonfils 
didik yang tidak menyelesaikan pelatihan. Peneliti mengajukan permohonan kaji etik kepada Komite Etik Penelitian FKUI/RSCM. Sebelum penelitian dimulai, dilakukan validasi alat penilai. Peserta menandatangani formulir persetujuan (informed consent). Instruktur mendemonstrasikan penggunaan alat Bonfils (gambar 1) dan setiap peserta diberi kesempatan melakukan intubasi sebanyak 2 kali untuk masingmasing pendekatan. Data yang terkumpul diolah menggunakan program Statistical Package for Social Sciences (SPSS) versi 21.0.

\section{HASIL PENELITIAN}

Jumlah subjek penelitian berdasarkan pengukuran besar sampel adalah 46 orang. Tim peneliti melakukan proses randomisasi untuk menentukan kelompok dan terbagi atas 23 orang kelompok 1 yang melakukan intubasi dengan Bonfils melalui pendekatan midline terlebih dahulu kemudian pendekatan retromolar dan kelompok 2 sebanyak 23 orang yang melakukan intubasi dengan Bonfils melalui pendekatan retromolar terlebih dahulu kemudian pendekatan midline, namun ada satu subjek yang sakit pada satu hari sebelum pengumpulan data pada kelompok 2, maka didapatkan subjek sebanyak 45 orang. Tim peneliti menggunakan per protocol analysis, sehingga satu subjek drop out tersebut tidak dianalisis karena tidak mengikuti pelatihan.

\section{Validitas dan Reliabilitas Alat Ukur Penelitian}

Validasi isi daftar tilik pengajaran intubasi dengan Bonfils dilakukan oleh pakar, yaitu dua orang staf pengajar Departemen Anestesiologi dan Terapi Intensif FKUI/RSCM. Validasi isi dilakukan dengan perhitungan Aiken's V. Ujian praktik pada pelatihan ini dinilai oleh dua orang penguji dan diolah dengan menggunakan Intraclass Correlation Coefficient.

\section{Karakteristik Subjek Penelitian}

Karakteristik subjek penelitian berupa usia, jenis kelamin, dan pengalaman subjek dalam mengikuti pelatihan intubasi dengan Bonfils sebelum pelatihan ini dilakukan. Sebagian besar subjek penelitian belum pernah mengikuti pelatihan intubasi dengan Bonfils sebelumnya.

Tabel 1. Karakteristik Subjek Penelitian

\begin{tabular}{ll}
\hline Karakteristik & Inhalasi Lidokain \\
\hline $\begin{array}{l}\text { Usia (tahun)* } \\
\text { Jenis Kelamin }\end{array}$ & $31,29(3,20)$ \\
$\qquad \begin{array}{l}\text { Lerempuan } \\
\text { Bellaki }\end{array}$ & $23(51,1)$ \\
Pernah mengikuti pelatihan Bonfils & $22(48,9)$ \\
Pernah & $40(88,9)$ \\
*Data disajikan dalam bentuk rerata (simpangan baku) \\
**Data disajikan dalam bentuk n (\%)
\end{tabular}

\section{Keberhasilan Intubasi dengan Bonfils}

Keberhasilan melakukan intubasi dengan Bonfils merupakan keberhasilan subjek dalam melakukan intubasi maksimal sebanyak dua kali percobaan. Hasil uji statistik menunjukkan tidak terdapat perbedaan bermakna keberhasilan intubasi dengan Bonfils melalui pendekatan midline dan retromolar pada DOPS 1, namun keberhasilan intubasi dengan Bonfils pada pendekatan midline signifikan lebih tinggi dibandingkan pendekatan retromolar pada DOPS 2 di jalan napas normal dan pada jalan napas sulit, dengan nilai $p<0,05$. 
Tabel 2. Keberhasilan Intubasi dengan Bonfils

\begin{tabular}{|c|c|c|c|c|}
\hline \multirow{2}{*}{ Karakteristik } & \multicolumn{2}{|c|}{ Pendekatan Retromolar } & \multirow{2}{*}{ Total } & \multirow{2}{*}{ Nilai P } \\
\hline & Berhasil & Tidak Berhasil & & \\
\hline \multicolumn{5}{|l|}{ Jalan Napas Normal } \\
\hline \multicolumn{5}{|l|}{ DOPS 1} \\
\hline Berhasil & $29(64,4)$ & $3(6,7)$ & $32(71,1)$ & 1,0000 \\
\hline Tidak Berhasil & $2(4,4)$ & $11(24,4)$ & $13(28,9)$ & \\
\hline \multicolumn{5}{|l|}{ DOPS 2} \\
\hline Berhasil & $31(68,9)$ & $8(17,8)$ & $39(86,7)$ & 0,008 \\
\hline Tidak Berhasil & $0(0,0)$ & $6(13,3)$ & $6(13,3)$ & \\
\hline \multicolumn{5}{|l|}{ Jalan Napas Sulit } \\
\hline Berhasil & $28(62,2)$ & $12(26,7)$ & $40(88,9)$ & 0,003 \\
\hline Tidak Berhasil & $1(2,2)$ & $4(8,9)$ & $5(11,1)$ & \\
\hline
\end{tabular}

* Data disajikan dalam bentuk rerata (simpangan baku)

**Data disajikan dalam bentuk $\mathrm{n}(\%)$

\section{Perbandingan Lama Waktu Intubasi dengan Bonfils}

Lama waktu melakukan intubasi dengan Bonfils dihitung mulai saat peserta memegang Bonfils hingga parumaneken mengembang saat dipompa dengan Bag Valve Mask yang dipastikan dengan auskultasi. Tidak terdapat perbedaan bermakna pada kedua pendekatan, serta nilai $\mathrm{p}=0,013$ pada jalan napas sulit yang menunjukkan terdapat perbedaan lama waktu intubasi dengan Bonfils pada pendekatan midline yang lebih cepat dibandingkan dengan menggunakan pendekatan retromolar.

\section{Perbandingan jumlah upaya intubasi dengan Bonfils}

Total upaya merupakan jumlah percobaan untuk memasukkan pipa endotrakeal hingga tepat melewati pita suara maneken, satu kali upaya didefinisikan sebagai usaha melakukan intubasi yang ditandai dengan pipa endotrakeal melewati gigi incisivus anterior. Tabel 4 menunjukkan terdapat perbedaan bermakna pada kedua pendekatan dalam melakukan intubasi dengan Bonfils.

Tabel 3. Perbandingan Lama Waktu Intubasi dengan Bonfils

\begin{tabular}{llll}
\hline Kelompok Perlakuan & $\begin{array}{c}\text { Pendekatan Midline } \\
\text { (detik) }\end{array}$ & $\begin{array}{c}\text { Pendekatan Retromolar } \\
\text { (detik) }\end{array}$ & Nilai P \\
\hline Jalan Napas Normal & $59(18-224)$ & $64(38-200)$ & 0,518 \\
Jalan Napas Sulit & $55(24-146)$ & $74,5(26-254$ & 0,013 \\
\hline
\end{tabular}

* Uji Mann-Whitney

\section{Perbandingan Keterampilan dan Pengetahuan Intubasi dengan Bonfils}

Keterampilan intubasi dengan Bonfils yang dilakukan oleh subjek dinilai berdasarkan daftar tilik pengajaran yang telah disusun oleh tim peneliti. Daftar tilik tersebut dijadikan penilaian DOPS dengan angka 1-10.
Penilaian DOPS dilakukan sebanyak dua kali pada saat performance dan pada saat ujian praktik. Tabel 5 menunjukkan tidak terdapat perbedaan keterampilan yang bermakna pada pendekatan midline maupun retromolar. Nilai pengetahuan pada penelitian ini dihitung berdasarkan hasil pretest dan posttest. 
Tabel 4. Perbandingan Jumlah Upaya Intubasi dengan Bonfils

\begin{tabular}{cccc}
\hline \multirow{2}{*}{ Karakteristik } & \multicolumn{2}{c}{ Pendekatan } & Nilai P \\
\cline { 2 - 3 } & Midline & Retromolar & \\
\hline Jalan Napas Normal & $29(64,4)$ & $16(35,6)$ & 0,006 \\
$2 x$ upaya & $10(22,3)$ & $15(33,3)$ & 0,020 \\
Jalan Napas Sulit & & & $21(46,7)$ \\
\hline
\end{tabular}

Tabel 5. Perbandingan Keterampilan melalui Penilaian DOPS dan Nilai Pengetahuan

\begin{tabular}{ccc}
\hline Karakteristik & Nilai & Nilai P \\
\hline Peningkatan Keterampilan DOPS & & \\
Pendekatan Midline & $2(-7-6)$ & 0,396 \\
Pendekatan Retromolar & $2(-4-6)$ & \\
Perbandingan Pengetahuan & & $<0,001$ \\
Pretest & $7(4-10)$ & \\
Posttest & $9(7-10)$ & \\
\hline
\end{tabular}

\section{PEMBAHASAN}

Kegagalan dalam melakukan intubasi endotrakeal, terlebih dalam manajemen jalan napas sulit merupakan penyebab utama terjadinya morbiditas dan mortalitas dalam anestesi. Intubasi dengan Bonfils dapat menjadi alternatif untuk dapat mengatasi hal tersebut. Keterbatasan alat Bonfils dan kesempatan belajar menyebabkan kurangnya menggunakan alat ini dalam praktik pembiusan sehari-hari. Tujuan penelitian ini adalah untuk mengetahui keberhasilan dan kemudahan dalam melakukan intubasi menggunakan Bonfils pada maneken melalui dua teknik pendekatan, yaitu midline dan retromolar, sehingga subjek penelitian mempunyai keterampilan yang lebih baik dalam mengaplikasikan Bonfils.

Proses pemahaman yang dilakukan subjek sebelumnya kemudian dilanjutkan dengan melakukan prosedur tersebut kembali sebagai latihan. Penerapan pembelajaran berbasis pengalaman berlaku pada penelitian ini. Subjek penelitian mempelajari kembali konsep yang diperlukan, berlatih kembali, hingga diperoleh suatu kemampuan yang lebih baik, sehingga mampu mengembangkan kemampuan dan dapat mencapai kompetensi yang diharapkan. ${ }^{6}$ Hal ini terbukti dalam penelitian ini berdasarkan uji statistik bahwa keberhasilan intubasi dengan Bonfils pada DOPS 2 bernilai bermakna dan juga sesuai dengan hipotesis penelitian bahwa keberhasilan intubasi dengan Bonfils pada pendekatan midline signifikan lebih tinggi dibandingkan dengan pendekatan retromolar pada DOPS 2 di jalan napas normal dan pada jalan napas sulit yang merupakan pengalamanketiga dan keempat bagi subjek dalam melakukan prosedur yang sama. Hasil penelitian ini 
sejalan dengan penelitian yang dilakukan oleh M. Halligan dan P. Charters yang dilakukan di Department of Anaesthesia, University Hospital Aintree, Lower Lane, UK pada tahun 2003, yang menunjukkan keberhasilan intubasi dengan Bonfils pada pendekatan midline lebih besar dibandingkan dengan pendekatan retromolar yang dilakukan pada jalan napas normal. ${ }^{4}$

Maneken yang digunakan saat penelitian berlangsung mempunyai kelebihan dapat dilakukan manipulasi, sehingga maneken intubasi tersebut selain dapat digunakan pada jalan napas normal, juga dapat digunakan untuk jalan napas sulit. Maneken tersebut menjadi mempunyai keterbatasan dalam melakukan ekstensi servikal dan keterbatasan dalam membuka mulut, walaupun kurang dari tiga jari, yaitu dua jari dalam pembukaan mulut, jika ingin digunakan untuk kasus jalan napas sulit.

Belum terdapat penelitian yang membandingkan intubasi dengan Bonfils melalui pendekatan midline dan retromolar pada kasus jalan napas sulit. Penelitian yang ada hanya membandingkan Bonfils dengan alat-alat intubasi lainnya, seperti laringoskop Macintosh dan intubating laryngeal mask airway untuk melakukan intubasi pada jalan napas sulit.,8 Intubasi dengan Bonfils memperoleh angka keberhasilan lebih tinggi dibandingkan dengan laringoskop Macintosh pada kasus keterbatasan pergerakan servikal dan pembukaan mulut, yaitu $81,6 \%$ pada Bonfils dan 39,5\% jika menggunakan laringoskop Macintosh. ${ }^{3}$ Berdasarkan hasil uji statistik pada penelitian ini diperoleh angka keberhasilan intubasi dengan Bonfils pada pendekatan midline signifikan lebih tinggi dibandingkan dengan pendekatan retromolar pada jalan napas sulit. Hal ini dapat disebabkan oleh beberapa faktor, yaitu keterampilan subjek yang sudah memahami teknik prosedur dengan lebih baik, percobaan keempat yang dilakukan subjek menjadikan subjek lebih mengenal struktur maneken yang digunakan, serta pembukaan mulut maneken yang tidak terlalu sempit sehingga masih memungkinkan bagi subjek untuk melakukan intubasi melalui pendekatan midline.

Penelitian yang dilakukan oleh M. Halligan dan P. Charters diperoleh data lama waktu intubasi pada pendekatan midline selama 44 (24-
180) detik dan pada pendekatan retromolar 25 (13-86) detik. Dari penelitian tersebut diperoleh hasil lama waktu intubasi dengan Bonfils melalui pendekatan midline lebih lama dibandingkan dengan pendekatan retromolar dan lama waktu yang digunakan juga lebih cepat. ${ }^{4} \mathrm{Hal}$ ini berbeda dengan hasil penelitian yang dilakukan. Beberapa kemungkinan yang menjadi penyebabnya adalah bahwa subjek sudah terbiasa melakukan visualisasi rongga mulut hingga menemukan glotis melalui pendekatan midline sama seperti yang dilakukan jika menggunakan laringoskop, pengalaman subjek yang kurang dalam menelusuri molar kemudian merotasikan Bonfils untuk dapat melihat laring/glotis pada saat melakukan pendekatan retromolar, serta pelatihan yang dilakukan pada maneken yang bersifat kaku dibandingkan dengan pasien sesungguhnya seperti yang dilakukan oleh M. Halligan dan P. Charters, sehingga untuk melakukan intubasi pada penelitian juga membutuhkan waktu yang lebih panjang.

Hasil uji statistik menunjukkan tidak terdapat perbedaan keterampilan yang bermakna pada pendekatan midline dan retromolar. Penilaian ini berdasarkan ada tidaknya peningkatan pada penilaian 10 butir daftar tilik pengajaran intubasi dengan Bonfils yang dilakukan pada DOPS 1 dan 2. Daftar tilik pengajaran ini cukup sederhana karena hanya terdiri dari 10 butir prosedur yang berurutan dan disusun berdasarkan penelitian yang dilakukan oleh $\mathrm{M}$. Halligan dan P. Charters. ${ }^{4}$ Hanya terdapat dua butir yang berbeda antara daftar tilik pengajaran intubasi dengan Bonfils pada pendekatan midline dan retromolar, yaitu cara memfiksasi mandibula dan cara memasukkan scope Bonfils ke dalam rongga mulut. Faktor tersebut yang menyebabkan tidak terdapat perbedaan bermakna di antara dua teknik tersebut. Hal ini berbeda pada nilai pengetahuan subjek yang dihitung dari nilai pretest dan posttest, yang menunjukkan terdapat perbedaan bermakna sebelum dan sesudah mendapatkan pelatihan. Hal ini menunjukkan komponen-komponen yang terdapat pada pelatihan ini, dimulai dari kuliah, demonstration prosedur oleh instruktur, dan performance yang dilakukan subjek menunjang proses pembelajaran dan bermanfaat dari segi 
kognitif. Hasil ini juga dapat dilihat dari tingginya tingkat kepuasan subjek penelitian melalui umpan balik pelatihan.

Penelitian ini merupakan pelatihan keterampilan prosedural yang merupakan serangkaian pelatihan keterampilan atau proses alih terampil suatu prosedur untuk dapat dikuasai oleh subjek. ${ }^{6}$ Sebagian besar subjek belum pernah mengikuti pelatihan Bonfils sebelumnya, maka dari itu penelitian ini memiliki keunggulan dalam hal adanya kesempatan khusus bagi subjek dalam memelajari teknik intubasi dengan Bonfils secara spesifik. Selain itu subjek penelitian yang merupakan PPDS Departemen Anestesiologi dan Terapi Intensif FKUI/RSCM tahap mandiri dan paripurna yang sudah menguasai manajemen jalan napas dengan baik, sehingga tidak sulit dalam proses pembelajaran ini, karena subjek mempunyai latar belakang mengenai intubasi yang serupa. Subjek juga dinilai aktif oleh instruktur dan penguji. Penelitian ini mempunyai keterbatasan dalam hal waktu. Hal ini menyebabkan kurangnya kesempatan dalam mempraktikkan langkah-langkah keterampilan prosedural yang dipelajari. Hal ini disebabkan karena jumlah subjek tidak didukung dengan ketersediaan maneken serupa yang hanya terdapat dua buah dan alat Bonfils yang terbatas tiga buah, sehingga proses pembelajaran terbatas oleh waktu. Keterbatasan pelatihan lainnya adalah alat ukur yang terlalu sederhana, hanya berbeda pada dua butir prosedural yaitu cara memfiksasi mandibula dan cara memasukkan scope Bonfils ke dalam rongga mulut, sehingga menyebabkan kurang terperinci dalam membedakan intubasi dengan Bonfils antara teknik pendekatan midline dan retromolar. Alat ukur tersebut juga tidak diucapkan oleh subjek penelitian saat mempraktikannya, sehingga hal ini menjadi salah satu bias dalam penilaian yang dilakukan oleh instruktur dan penguji. Setiap langkah dalam daftar tilik tersebut hanya dilakukan dan tidak diucapkan oleh subjek untuk menghindari bias yang mungkin terjadi dalam pengukuran lama waktu melakukan intubasi dengan Bonfils.

\section{SIMPULAN}

Keberhasilan dan kemudahan intubasi dengan Bonfils melalui teknik pendekatan midline lebih baik dibandingkan dengan teknik pendekatan retromolar pada maneken.

\section{SARAN}

Alat ukur dalam penelitian ini dapat dimodifikasi menjadi lebih rinci sehingga dapat lebih baik dalam membedakan kedua teknik pendekatan. Pelatihan intubasi dengan Bonfils melalui pendekatan midline dapat diaplikasikan untuk PPDS dan selanjutnya dapat dilakukan kepada pasien sesungguhnya.

\section{DAFTAR PUSTAKA}

1. Noppens R, Piepho T, Gagstatter F. The Bonfils intubation endoscope in clinical and emergency medicine. 1st ed. Department of Anesthesiology, University Medical Centre of the Johannes Gutenberg University Mainz; 2011. 8-44 p.

2. Thong SY, Wong TGL. Clinical uses of the bonfils retromolar intubation fiberscope: A review. Int Anesth Res Soc. 2012;115(4):855-66.

3. Shollik NA, Ibrahim SM, Ismael A, Agnoletti V, Piraccini E, Corso RM. Use of the Bonfils Intubation Fiberscope in Patients with Limited Mouth Opening. Case Rep Anesthesiol. 2012; p. 1-3.

4. Halligan M, Charters P. A clinical evaluation of the Bonfils Intubation Fibrescope. Anaesthesia. 2003;58:1087-91.

5. Khanghahi ME, Azar FEF. Direct observation of procedural skills (DOPS) evaluation method: Systematic review of evidence. Med J Islam Repub Iran. 2018;

6. Findyartini A, Menaldi SLS, Jusuf A. Prinsip pengajaran praktik klinis dan prinsip supervisi praktik klinis. Jakarta: Sagung Seto; 2017. p. 3-17.

7. Bein B, Worthmann F, Scholz J, Brinkmann F, Tonner $\mathrm{PH}$, Steinfath $\mathrm{M}$, et al. A comparison of the intubating laryngeal mask airway and the Bonfils intubation fibrescope in patients with predicted difficult airways. Anaesthesia. 2004; ;59:1207-9.

8. Limbach $\mathrm{T}$, Ott $\mathrm{T}$, Griesinger J, JahnEimermacher A, Piepho T. Bonfils intubation fibrescope: Use in simulationbased intubation training for medical students in comparison to Maclntosh laryngoscope. BMC Res Notes. 2016;(9):127. 